Article

\title{
Identification of Self-Incompatibility Alleles by Specific PCR Analysis and S-RNase Sequencing in Apricot
}

\author{
Sara Herrera ${ }^{1}$, Javier Rodrigo ${ }^{1}{ }^{\mathbb{D}}$, José I. Hormaza ${ }^{2}$ and Jorge Lora ${ }^{2, *(D)}$ \\ 1 Unidad de Hortofruticultura, Centro de Investigación y Tecnología Agroalimentaria de Aragón (CITA), \\ Instituto Agroalimentario de Aragón-IA2 (CITA-Universidad de Zaragoza), 50059 Zaragoza, Spain; \\ sherreral@aragon.es (S.H.); jrodrigo@cita-aragon.es (J.R.) \\ 2 Instituto de Hortofruticultura Subtropical y Mediterránea La Mayora (IHSM La Mayora-UMA-CSIC), \\ 29750 Algarrobo-Costa, Málaga, Spain; ihormaza@eelm.csic.es \\ * Correspondence: jlora@eelm.csic.es; Tel.: +34-952-54-89-90
}

Received: 28 September 2018; Accepted: 13 November 2018; Published: 15 November 2018

\begin{abstract}
Self-incompatibility (SI) is one of the most efficient mechanisms to promote out-crossing in plants. However, SI could be a problem for fruit production. An example is apricot (Prunus armeniaca), in which, as in other species of the Rosaceae, SI is determined by an S-RNase-based-Gametophytic Self-Incompatibility (GSI) system. Incompatibility relationships between cultivars can be established by an S-allele genotyping PCR strategy. Until recently, most of the traditional European apricot cultivars were self-compatible but several breeding programs have introduced an increasing number of new cultivars whose pollination requirements are unknown. To fill this gap, we have identified the $S$-allele of 44 apricot genotypes, of which 43 are reported here for the first time. The identification of $S_{c}$ in 15 genotypes suggests that those cultivars are self-compatible. In five genotypes, self-(in)compatibility was established by the observation of pollen tube growth in self-pollinated flowers, since PCR analysis could not allowed distinguishing between the $S_{c}$ and $S_{8}$ alleles. Self-incompatible genotypes were assigned to their corresponding self-incompatibility groups. The knowledge of incompatibility relationships between apricot cultivars can be a highly valuable tool for the development of future breeding programs by selecting the appropriate parents and for efficient orchard design by planting self-compatible and inter-compatible cultivars.
\end{abstract}

Keywords: apricot; Gametophytic Self-Incompatibility; pollen TUBE; pollination; Prunus armeniaca; $S$-alleles; S-genotype

\section{Introduction}

Different physical and genetic strategies have been developed by plants to prevent self-pollination and promote out-crossing, and thus, ensure genetic variability [1]. A physical barrier can be found in bisexual flowers by different temporal maturation of the male and female parts (dichogamy) or by a spatial separation of the female and male parts (herkogamy) [2]. The genetic barrier, self-incompatibility (SI), is considered to be one of the most efficient mechanisms to promote out-crossing [3]. SI is a widespread mechanism that has been reported in nearly one-half of angiosperm species [4]. However, SI has only been characterized in a few families and the underlying molecular and genetic factors that are involved in SI have only been described in detail in the Sporophytic Self-Incompatibility System (SSI) and in the Gametophytic Self-Incompatibility System (GSI) [5]. In those systems, self-incompatibility is genetically controlled by a multiallelic locus named $S$ [6]. Following the discovery of sporophytic and gametophytic incompatibility [6], an array of other incompatibility 
systems, such as late-acting self-incompatibility [7] or cryptic self-incompatibility [8], have been reported in different families, although the cells and the mechanisms that are involved have not been identified. Interestingly, cryptic self-incompatibilty has been found in herkogamous species in which the growth of cross-pollen tubes is faster than that of self-pollen tubes [7], a pollen tube behavior that, to the best of our knowledge, has not been studied in GSI and should also be taken into account. However, this scenario has not been described in Rosaceae and it seems unlikely to occur in this family [9].

SSI has been mainly characterized in the Brassicaceae family [10]. In SSI, recognition factors are coded by the sporophyte and deposited extra-cellularly on the pollen grain wall. Pollen germination is arrested at the stigma surface when the $S$-allele of the haploid pollen matches either of the $S$-alleles of the diploid pistil [11]. GSI is the most abundant SI in angiosperms and it has been characterized in 18 families, including the Rosaceae [7]. GSI is controlled by a multiallelic locus $S$, which encodes the stylar and pollen $S$-determinants, and cell-cell recognition generally takes place in the style during pollen tube growth [12]. The stylar S-determinant, a ribonuclease (S-RNase), is a glycoprotein secreted into the style mucilage [13] that is composed of five highly conserved regions (C1-C5). Additionally, a single hypervariable region (RHV) is found in the S-RNase of Rosaceae, while two hypervariable regions ( $\mathrm{HVa}$ and $\mathrm{HVb}$ ) are observed in the S-RNase of Solanaceae and Plantaginaceae [14]. The pollen $S$-determinant is an F-box protein that contains two variable (V1 and V2) and two hypervariable $(\mathrm{HVa}$ and $\mathrm{HVb}$ ) regions, and it is coded by pollen-specific F-box genes (SFB) [15].

Rosaceae constitutes the third most economically important family in temperate regions of the world, including several important crops, such as pear (Pyrus communis), apple (Malus domestica), sweet cherry (Prunus avium), almond (Prunus dulcis), and apricot (Prunus armeniaca) [16]. Most European common apricot cultivars have been traditionally considered as self-compatible [17]. However, with the purpose of introducing a source of resistance to sharka, some incompatible cultivars that were developed in North America have been used as parents in several breeding programs [18,19]. Sharka is the most important virus disease affecting Prunus in Europe and it has caused important economic damages in the last decades, becoming a limiting factor for apricot production in some areas. The release of these new breeding lines has resulted in the introduction of an increasing number of new apricot cultivars with unknown incompatibility information.

Self and intercompatibility relationships have been traditionally determined by performing field-controlled pollinations. The (in)compatibility is established by recording the percentage of fruit set four weeks after self- and cross-pollinations [20,21]. However, the efficiency of this method is conditioned by uncontrolled environmental factors [22]. Incompatibility can also be evaluated by observing pollen tube growth through the style in hand-pollinated flowers under the microscope. The stigma of apricot is papillate and wet, and the style shows a compact transmitting tissue enveloped by vascular bundles. Pollen grains germinate on the moist surface of the stigma within one day after pollination. The pollen tube penetrates into the stigma between the papillae, reaches the transmitting tissue and grows along the style in the following days. Pollen tube growth along the style takes 3-4 days [22]. However, pollen tube behavior can also be affected by environmental factors, mainly temperature. Thus, warm temperatures prior to flower opening result in lower fruit set, related to an asynchrony between the reproductive organs and the showy part of the flower [22]. Moreover, high temperatures can accelerate pollen tube growth kinetics [23]. Thus, in order to minimize environmental effects, the (in)compatibility phenotype can be evaluated in semi-in vivo culture of flowers in laboratory-controlled self- and cross-pollinations, followed by the subsequent observation of pollen tube behavior through the style under a fluorescence microscopy. This approach has been successfully used to determine self-(in)compatibily and incompatibility relationships between cultivar, in apricot [24] and other Prunus species [25].

Moreover, since the first isolation of a partial cDNA encoding an S-locus specific glycoprotein from Brassica oleracea [26], the development of molecular techniques based on the sequence of the $S$-locus has allowed for the identification of self-(in)compatibility and the incompatibility relationships 
among cultivars in numerous species. In Prunus, the sequence of the S-RNase revealed two introns with considerable length polymorphism that have been used to distinguish among S-haplotypes [27-31]. Thirty-three alleles have been reported so far in apricot $\left(S_{1}\right.$ to $S_{20}, S_{22}$ to $\left.S_{30}, S_{52}, S_{53}, S_{v}, S_{x}\right)$, including one allele for self-compatibility $\left(S_{c}\right)$ [32-36]. Additional alleles have been included in the NCBI database but not yet published showing misidentification and the appearance of numerous homologies [24,35]. $S$-genotyping has allowed for classifying the cultivars in their corresponding incompatibility group according to their compatibility relationships. Self-incompatibility is considered when the genotype of pollen matches with one of the $S$-alleles of the pistil. Thus, those self-incompatible cultivars with the same $S$-alleles are inter-incompatible and are allocated in the same incompatibility group, whereas cultivars from different groups with at least one different $S$-allele are inter-compatible [35]. In apricot, 23 incompatibility groups have been stablished [24,37-40], which provides useful information to apricot growers and breeders.

To fill the lack of knowledge on self-(in)compatibility and incompatibility relationships in the increasing number of new apricot cultivars, in this work we identified the $S$-genotype of 44 apricot cultivars and selections by PCR analysis, and classified them according to their S-RNase alleles in nine incompatibility groups. Of those, the $S$-genotype of 43 is reported here for the first time. Additionally, in those cases in which the $S$-genotype could not be identified by molecular approaches, self-incompatibility was established by the observation of pollen tube behavior under the microscope following self-pollination. Our results elucidated incompatibility relationships among a high number of apricot cultivars with previous unknown pollination requirements providing valuable information to design new crosses in apricot breeding programs and selecting self-compatible and inter-compatible varieties in new apricot orchards.

\section{Results}

Self-compatibility of 44 cultivars and selections (Table 1) was evaluated by S-RNase allele identification using PCR analysis, amplifying the conserved regions of the apricot $S$-RNase locus. We first identified the S-RNase alleles using the primers SRc-F/SRc-R for the amplification of the first intron (Tables 1 and 2, Figure 1). Because some $S$-RNase alleles, such as $S_{1}$ and $S_{7}$ or $S_{6}$ and $S_{9}$ showed amplified fragments of similar size of the first intron in 27 genotypes, we also used the primers Pru-C2 and PruC4R that amplify the second S-RNase intron. These additional primers enabled identifying the $S$-allele of 13 of those 27 genotypes. The primers Pru-C2 and PruC4R also amplified a fragment of $2 \mathrm{~kb}$ in the genotype 'T007'. This fragment size in the second intron has not been previously reported in other apricot cultivars. Thus, we further analyzed this PCR fragment by cloning and sequencing (Figure S1). We obtained a sequence of $2002 \mathrm{bp}$ that showed a $99 \%$ of identity with the $S_{20}$ allele (EF160078, [34]) and the unpublished $S_{55}$ allele (KT223014). Thus, we identified one of the alleles of the $S$-genotype of 'T007' as $S_{20}$.

The combination of the primers Pru-C2 and PruC4R was inefficient in 15 genotypes with no amplification fragments obtained. Therefore, new specific primers were designed to amplify the second intron of the $S_{1}$ and $S_{7}$ alleles (Table 2, Figure 1). The primers SHLM1 and SHLM2 amplified a fragment of $650 \mathrm{bp}$ from the $S_{1}$ allele (Figures 1 and 2). However, while the sequence of $S_{1}$ has been previously reported [41] (AY587561), the $S_{7}$ allele has only been identified by PCR analysis and no sequence has been yet included in the NCBI database. Thus, using the primers Pru-C2 and PruC4R, we cloned and sequenced the fragment of $900 \mathrm{bp}$ that was obtained from the cultivar 'Charisma' $\left(S_{c} / S_{7},[24]\right)$, which corresponds to the $S_{7}$ allele [33]. Surprisingly, the cloned sequence resulted in a fragment of $915 \mathrm{bp}$ (Figure S2) that showed a 99\% identity with the partial coding sequence (790 bp, EF062341, unpublished), of the $S_{13}$ allele and with a fragment of $830 \mathrm{bp}$ that corresponds to the unpublished $S_{46}$ allele (HQ342876). The $S_{13}$ allele (DQ870629) has also been identified by Zhang et al. [34], but the sequence of the gen bank accessions EF062341 and DQ870629 are different, and, consequently, both sequences have been considered as two different $S$-alleles. Our results suggest that $S_{7}, S_{13}$ (EF062341), and $S_{46}$ could indeed be the same allele. Based on the sequence of $915 \mathrm{bp}$, 
we designed the primers SHLM3 and SHLM4 that amplified a fragment of $413 \mathrm{bp}$. The primers Pru-C2/PruC4R, SHLM1/SHLM2, and SHLM3/SHLM4 enabled the identification of the $S$ genotype of 27 additional cultivars and selections (Table 1 ).

Table 1. Incompatibility groups and S-RNase genotype of the 44 apricot cultivars and selections analyzed in this study.

\begin{tabular}{|c|c|c|}
\hline Incompatibility Group & S-RNase Genotype & Apricot Genotypes Analyzed in this Study \\
\hline \multirow[t]{3}{*}{ I } & $S_{1} S_{2}$ & T069 \\
\hline & & T120 \\
\hline & & T139A \\
\hline II & $S_{8} S_{9}$ & $\mathrm{C}_{007^{1}}$ \\
\hline $\mathrm{V}$ & $S_{2} S_{8}$ & $\mathrm{C} 012^{1}$ \\
\hline \multirow[t]{2}{*}{ VIII } & $S_{6} S_{9}$ & Cheyenne \\
\hline & & T001 \\
\hline XVIII & $S_{1} S_{3}$ & A150 \\
\hline \multirow{2}{*}{ XXII } & $S_{3} S_{9}$ & A153 \\
\hline & & Kosmos \\
\hline XXIV $^{2}$ & $S_{1} S_{6}$ & Primaya \\
\hline$X X V^{2}$ & $S_{1} S_{9}$ & A106 \\
\hline$X X V I^{2}$ & $S_{6} S_{8}$ & $\mathrm{C} 009^{1}$ \\
\hline \multirow{31}{*}{ Self-compatible cultivars } & $S_{2} S_{c}$ & Kalao \\
\hline & & Regibus \\
\hline & $S_{3} S_{c}$ & $\mathrm{C} 014^{1}$ \\
\hline & & Rambo \\
\hline & $S_{4} S_{c}$ & T002 \\
\hline & $S_{7} S_{c}$ & Beliana \\
\hline & $S_{9} S_{c}$ & $\mathrm{C}_{003^{1}}$ \\
\hline & & Lido \\
\hline & $S_{c}$ & Dorada \\
\hline & & Memphis \\
\hline & & Milord \\
\hline & & Murciana \\
\hline & & Oscar \\
\hline & & Sherpa \\
\hline & & T003 \\
\hline & $S_{1}$ & A154 \\
\hline & & T004 \\
\hline & & T005 \\
\hline & & T109 \\
\hline & & T124 \\
\hline & & T139B \\
\hline & & T140 \\
\hline & $S_{2}$ & Cyrano \\
\hline & & T098 \\
\hline & $S_{3}$ & Mikado \\
\hline & & T006 \\
\hline & $S_{7}$ & T116 \\
\hline & $S_{9}$ & A151 \\
\hline & & A152 \\
\hline & & A155 \\
\hline & $S_{20}$ & T007 \\
\hline
\end{tabular}

\footnotetext{
${ }^{1} S_{c} / S_{8}$ allele identified using fluorescence microscopy; ${ }^{2}$ Incompatibility groups first reported in this study.
} 
Table 2. Primers used in this study for the identification of S-alleles in Prunus armeniaca.

\begin{tabular}{|c|c|c|c|}
\hline Primers & Amplified Region & Sequence $\left(5^{\prime} \rightarrow 3^{\prime}\right)$ & Reference \\
\hline SRc-F & S-RNase 1st intron & CTCGCTTTCCTTGTTCTTGC & [41] \\
\hline SRc-R & S-RNase 1st intron & GGCCATTGTTGCACCCCTTG & [41] \\
\hline Pru-C2 & S-RNase 2nd intron & CTTTGGCCAAGTAATTATTCAAACC & [27] \\
\hline Pru-C4R & S-RNase 2nd intron & GGATGTGGTACGATTGAAGCG & [27] \\
\hline AprFBC8-F & $S F B$ & CATGGAAAAAGCTGACTTATGG & [39] \\
\hline AprFBC8-R & $S F B$ & GCСТCTAATGTCATCTACTCTTAG & [39] \\
\hline SHLM1-F ${ }^{1}$ & $S_{1}$-RNase 2nd intron & GGTGGAGGTGATAAGGTAGCC & \\
\hline SHLM2-R ${ }^{1}$ & $S_{1}-R N a s e$ 2nd intron & GGCTGCATAAGGAAGCTGTAGG & \\
\hline SHLM3-F ${ }^{1}$ & $S_{7}-R N a$ se 2 nd intron & TATATCTTACTCTTTGGC & \\
\hline SHLM4-R ${ }^{1}$ & $S_{7}-R N a s e$ 2nd intron & CACTATGATAATGTGTATG & \\
\hline
\end{tabular}

${ }^{1}$ Specific primers designed in this study.

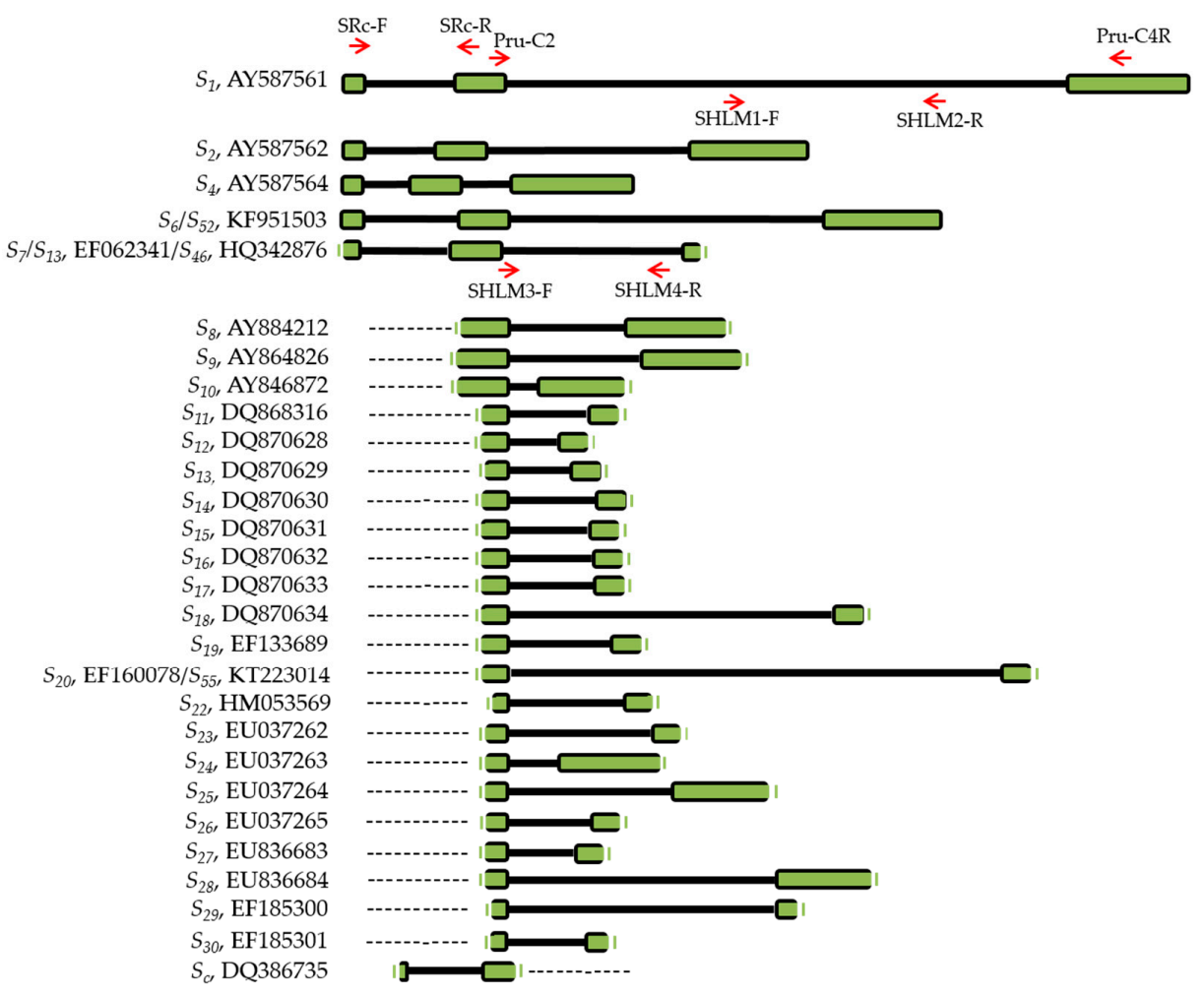

Figure 1. Gene structure of the $S$-alleles sequenced, showing the exons in green square and including the primers used in this study for the alleles $S_{1}$ and $S_{7} / S_{13} / S_{46}$. Unknown sequences are represented by dotted lines. The first column shows $S$-genotype and gen bank accession. $S_{1}$ [41], $S_{2}$ [41], $S_{3}$ [41], $S_{4}$ [41], $S_{6} / S_{52}, S_{7} / S_{13}$ and $S_{46}$ [Unpublished], $S_{8}$ [42,43], $S_{9}$ [42], $S_{10}$ [42], $S_{11}$ [34], $S_{12}$ [34], $S_{13}$ [34], $S_{14}$ [34], $S_{15}$ [34], $S_{16}$ [34], $S_{17}$ [34], $S_{18}$ [34], $S_{19}$ [34], $S_{20}$ [34] $/ S_{55}$ [Unpublished], $S_{22}$ [44], $S_{23}$ [44], $S_{24}[44], S_{25}[44], S_{26}[44], S_{27}[44], S_{28}[44], S_{29}[44], S_{30}[44], S_{c}[43]$.

Due to the identical sequence of the RNase gene in the $S_{c}$ and $S_{8}$ haplotypes [43], the pairs of primers SRc-F/SRc-R and Pru-C2/PruC4R could not be used for distinguishing between those two alleles. Therefore, the $S_{c}$ and $S_{8}$ alleles can only be identified using the primers AprFBC8-F and AprFBC8-R that amplify a fragment of approximately $500 \mathrm{bp}$ in the $S_{c}$ allele and $150 \mathrm{bp}$ in the $S_{8}$ allele from the $\mathrm{V} 2$ and $\mathrm{HVb}$ variable regions of the SFB gene [39]. Thus, the S-genotype of 13 cultivars was identified using the primers AprFBC8-F and AprFBC8-R (Table 2). Moreover, self-(in)compatibility was also evaluated by direct observation of pollen tube growth in the pistil after self-pollination in five selections ("C003", "C007", “C009", “C012", and "C014"), in which the primers 
AprFBC8-F/AprFBC8-R were not able to differentiate between the $S_{c}$ and $S_{8}$ alleles. Pollen germination was observed on the stigma in all cultivars. Pollen tube growth was arrested in the upper half of the style, showing a terminal callose plug and end thickening (Figure 3A) in three genotypes ("C007", "C009", and "C012") that were considered as self-incompatible. Self-compatibility was considered in two genotypes ("C003" and "C014"), in which the pollen tubes grew along the style (Figure 3B) and at least one of them reached the base of the style in most of the pistils that were analyzed (Figure 3C). As expected, the pollen used was viable and all cross-pollinated pistils displayed pollen tubes at the base of the style (Table 3).

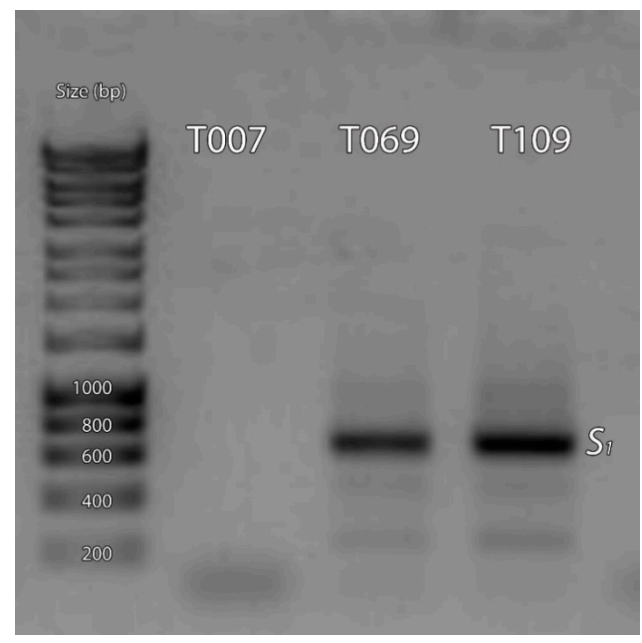

Figure 2. PCR amplification of the RNase second intron region using the specific primers SHLM1 and SHLM2 for the identification of the $S_{1}$ allele in T007 $\left(S_{20}\right)$, T069 $\left(S_{1} S_{2}\right)$, and T109 $\left(S_{1}\right)$.
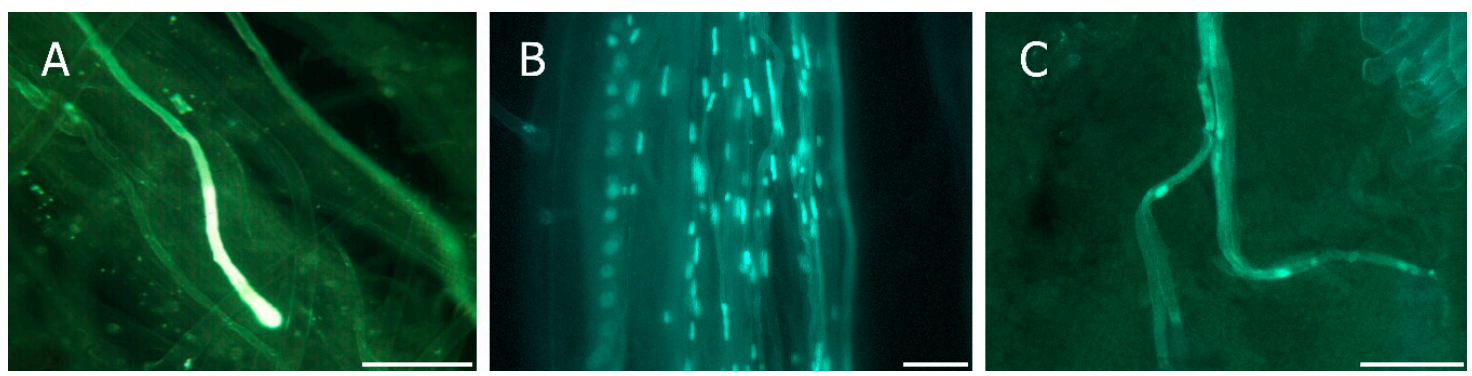

Figure 3. Pollen tube growth in apricot pistils. (A) Pollen tube arrested in the upper half of the style in a self-incompatible cultivar; (B) Pollen tubes growing along the style; and, (C) Pollen tubes at the base of the style in a compatible cross. Scale bars, $100 \mu \mathrm{m}$.

Table 3. Pollen tube behavior in the pistils of five apricot selections after self- and cross-pollinations.

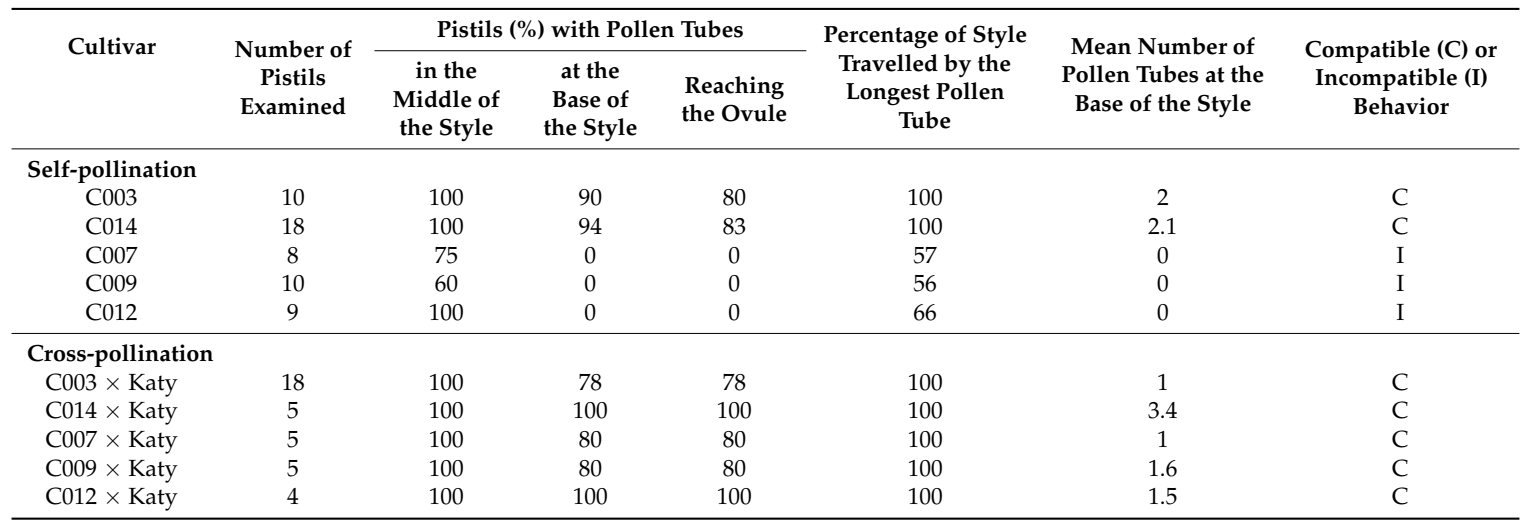




\section{Discussion}

The $S$-allele composition of 44 apricot genotypes, including new cultivars and advanced selections of three breeding programs, of which 43 have been reported here for the first time, has been identified. $S$-genotyping by PCR analysis allowed for the identification of the two S-alleles in 21 genotypes. Approximately half of the genotypes analyzed (55\%) were self-compatible, including commercial cultivars, such as "Murciana" or "Dorada" [45,46]. The remaining genotypes, mostly advanced breeding selections, were considered as self-incompatible. This $S$-allele identification can speed up breeding programs by selecting self-compatible genotypes at the seedling stage or genotypes with the desired $S$-allele composition. The results confirm the tendency of the increase in the number of self-incompatibility genotypes in apricot that is in contrast with the previous scenario, when most European cultivars were self-compatible [47].

According to their $S$-allele composition, 13 self-incompatible cultivars have been allocated in nine previously determined incompatibility groups [24,37-40]. "Primaya" $\left(S_{1} S_{6}\right)$, "A106" $\left(S_{1} S_{9}\right)$, and "C009" $\left(S_{6} S_{8}\right)$ have been assigned to XXIV-XXVI groups, three new incompatibility groups that have been reported herein for the first time. By contrast, 15 cultivars had the $S_{c}$ allele and they were characterized as self-compatible, and, consequently, can be considered as universal pollen donors. Results herein confirm the $S$-alleles of 'Beliana' $\left(S_{c} S_{7}\right)$ [48]

The PCR fragment of the first intron of $S_{8}$ was identical to $S_{c}$. Moreover, both S-RNases showed equal isoelectric points [43], suggesting that the S-RNase of $S_{8}$ and $S_{c}$ alleles are identical. Thus, it is likely that $S_{c}$ could derive from the $S_{8}$ allele [43]. In this case, as it has also been reported in other Prunus species [25,49], the breakdown of the incompatibility system can be related to a mutation outside of the $S$-locus [50]. Indeed, an insertion of $358 \mathrm{bp}$ in the SFB gene causes a loss of the incompatibility [50] that was also observed in the $S F B_{c}$ gene but not in the sequence of $S F B_{8}$ [43]. That is why primers have been designed based on the $S F B$ sequence for the identification of $S_{c}$ and $S_{8}$, such as the primer pair AprFBC8-R/F. Thus, using these primers, we could distinguish between $S_{c}$ and $S_{8}$ in 13 apricot genotypes. However, $S_{c}$ and $S_{8}$ could not be distinguished in five genotypes. Although the PCR-based method has been a preferred technique for $S$-allele identification, mismatching of PCR primers can result in no amplification. This might be the case in these five selections, in which an amplified fragment was not obtained using the primer pair AprFBC8-R/F. As an alternative, we performed controlled pollinations that were carried out in the laboratory and pollen tube growth was observed under the microscopy to determine self-(in)compatibility. The results showed that two genotypes behaved as self-compatible and they were assigned with allele $S_{c}$, whereas the other three were self-incompatible and were assigned with allele $S_{8}$.

The inaccuracy of the PCR-based method could also be reflected in the amplification of just one allele. Indeed, 23 of the 44 genotypes that were analyzed in this work show only one $S$-allele after PCR amplification. This could be due either to homozygosis in the case of the $S_{c}$ allele or with amplification problems in the other genotypes. Thus, the S-genotype of "Dorada", "Memphis", "Milord", "Murciana", "Oscar", "Sherpa", and "T003"is likely to be $S_{c} S_{c}$. Further sequencing work is under way to identify the other $S$ allele in the remaining 16 genotypes. $S$-allele analysis by band identification in a gel can also provide inaccurate identification. It also should be taken into account that the $S$-RNase sequence has only been revealed in some $S$-alleles, and, in most of the cases, such as $S_{9}, S_{15}$, or $S_{27}$, it has been only partially sequenced, and/or not including introns that are essential for fragment sizing in $S$-allele identification. The use of an automatic fragment analyzing system can also report small differences in fragment size; for example, in $S_{2}$ allele (327 bp [33]; 334 bp [24]; $332 \mathrm{bp}$ [51]) or $S_{c}$ (353 bp [33]; $358 \mathrm{bp}$ [24]; $355 \mathrm{bp}$ [51]). Taken together, all this has led to numerous homologies $[2,4,35]$. That is the case of $S_{6}$ and $S_{52}$ [24] or $S_{20}$ and $S_{55}$, and $S_{7}, S_{13}\left(\right.$ EF062341) and $S_{46}$ shown in this study.

There is a need to standardize the criteria for the $S$-allele identification in different laboratories, such as the use of the same primer pairs and the complete sequencing of the $S$-alleles, including introns. This will facilitate $S$-allele identification avoiding confusion and it will provide valuable information 
for apricot growers and breeders. Results herein allow for establishing incompatibility relationships among apricot cultivars with previous unknown pollination requirements, allowing the selection of the appropriate parents in the design of new crosses in apricot breeding programs and self-compatible and inter-compatible cultivars in new commercial orchards. Moreover, the approach that is followed in this work can be of interest to other fruit crops in the Rosaceae with similar problems to those faced by apricot.

\section{Materials and Methods}

\subsection{Plant Material}

Plant material was collected from different apricot germplasm collections and orchards of Aragon, Cataluña, and Extremadura (Spain). Young leaves from 16 new apricot cultivars and 28 advanced selections from different breeding programs were used in this study for PCR analysis (Table 1). Moreover, flowers were collected from five of the selections ("C003", "C007", "C009", "C012", and "C014") for pollination experiments (Table 3).

\subsection{DNA Extraction}

Young leaves from the 44 cultivars and selections were collected for the identification of self-incompatibility alleles. Genomic DNA was extracted following the protocol described by Hormaza [52] and using a DNeasy Plant Mini Kit (Qiagen, Hilden, Germany). The DNA quantification was performed by using a NanoDrop ${ }^{\mathrm{TM}}$ ND-1000 spectrophotometer (Bio-Science, Budapest, Hungary).

\subsection{S-RNase Allele Identification by PCR Analysis}

Self-incompatibility was stablished by $S$-allele identification through PCR amplification of RNase and $S F B$ regions. Fluorescently labelled forward primer SRc-F with the reverse primer SRc-R $[33,41]$ were used to amplified the first intron region of the S-RNase gene. PCR amplifications were carried out in $15 \mu \mathrm{L}$ reaction volumes, containing $10 \times \mathrm{NH}_{4}$ Reaction Buffer, $25 \mathrm{mM} \mathrm{Cl}_{2} \mathrm{Mg}, 2.5 \mathrm{mM}$ of each dNTP, $10 \mu \mathrm{M}$ of each primer, $100 \mathrm{ng}$ of genomic DNA, and $0.5 \mathrm{U}$ of BioTaq ${ }^{\mathrm{TM}}$ DNA polymerase (Bioline, London, UK). The temperature profile used had an initial step of $3 \mathrm{~min}$ at $94{ }^{\circ} \mathrm{C}, 35$ cycles of $1 \mathrm{~min}$ at $94{ }^{\circ} \mathrm{C}, 1 \mathrm{~min}$ at $55^{\circ} \mathrm{C}$ and $3 \mathrm{~min}$ at $72{ }^{\circ} \mathrm{C}$, and a final step of $5 \mathrm{~min}$ at $72{ }^{\circ} \mathrm{C} . S_{c}$ and $S_{8}$ alleles had an identical fragment length of $355 \mathrm{bp}$ from the first intron, amplified using the primers SRc-(F/R) [42,43]. Thus, the SFB specific primers, AprFBC8-F and AprFBC8-R, were used to distinguish between both alleles. The identification was carried out according to the PCR conditions of Halasz et al. [39]. The sizes of the products that were obtained by PCR were analyzed in a CEQ ${ }^{\mathrm{TM}} 8000$ capillary electrophoresis DNA analysis system (Beckman Coulter, Fullerton, CA, USA) and compared and classified according to Vilanova et al. [33] and Kodad et al. [51]. For the amplification of the RNase second intron region, the primers Pru-C2 and Pru-C4R were used, as recommended by Vilanova et al. [33], but with the addition of 10 cycles and using $55^{\circ} \mathrm{C}$ of annealing temperature, as indicated by Sonneveld et al. [53]. The amplified fragments were separated on $1 \%(w / v)$ agarose gels and DNA bands were visualized using the nucleic acid stain SYBR Green (Thermo Scientific, St Leon-Rot, Germany).

Since the PruC2/PruC4R primer combination was inefficient to distinguish $S_{1}$ and $S_{7}$ alleles, new specific primers were designed from the second intron, SHLM1 and SHLM2 for the identification of the $S_{1}$-haplotype and SHLM3 and SHLM4 for the identification of the $S_{7}$ haplotype (Table 2, Figure 1). For $S_{1}$ identification, Taq DNA polymerase (Qiagen, Hilden, Germany) was used with a temperature profile of an initial step of $94{ }^{\circ} \mathrm{C}$ for $2 \mathrm{~min}, 35$ cycles of $94{ }^{\circ} \mathrm{C}$ for $30 \mathrm{~s}, 62{ }^{\circ} \mathrm{C}$ for $1 \mathrm{~min}$ and $30 \mathrm{~s}$ and $72{ }^{\circ} \mathrm{C}$ for $2 \mathrm{~min}$, and a final extension of $72{ }^{\circ} \mathrm{C}$ for $5 \mathrm{~min}$. For $S_{7}$ identification, the amplification was performed using Phusion ${ }^{\circledR}$ High-Fidelity DNA Polymerase (Thermo Scientific, St Leon-Rot, Germany) with the following temperature profile: $30 \mathrm{~s}$ at $98^{\circ} \mathrm{C}, 35$ cycles of $10 \mathrm{~s}$ at $98^{\circ} \mathrm{C}, 30 \mathrm{~s}$ at $51^{\circ} \mathrm{C}$, and $1 \mathrm{~min}$ at $72{ }^{\circ} \mathrm{C}$, with a $5 \mathrm{~min}$ final extension step at $72{ }^{\circ} \mathrm{C}$. 


\subsection{Sequencing of Genomic PCR Products}

In order to design $S_{7}$-specific primers, a fragment of 900 bp obtained by using the primers PruC2/PruC4R was isolated using the NucleoSpin Gel and PCR Clean-up (Macherey-Nagel, Düren, Germany). Cloning was performed using CloneJET PCR Cloning Kit (Thermo Scientific, St Leon-Rot, Germany) and by electroporation in E. coli Single-Use JM109 Competent Cells (Promega Biotech Ibérica SL, Madrid, Spain). The search for similarities in the sequences of the NCBI database was performed with BLAST (http:/ / www.ncbi.nlm.nih.gov/BLAST, version 2.2.10).

\subsection{Pollination Experiments}

Pollination crosses were carried out with the five selections in which the identification of the $S_{8}$ and $S_{c}$ alleles was not possible by PCR amplification. To establish self-(in)compatibility, self-pollinations and cross-pollinations were carried out in semi-in vivo culture of flowers in the laboratory and pollen tube growth was observed under fluorescence microscopy. As control, flowers of each cultivar were pollinated with pollen from the cultivar "Katy", which is known as the universal pollinizer for apricot (Table 3) [54].

For each self- and cross-pollination, a group of 20-25 flowers was collected from the trees at the balloon stage (Figure 4A), corresponding to stage 58 on the $\mathrm{BBCH}$ scale for apricot [55]. Flowers were emasculated in the laboratory to avoid self-pollination, placed on florist foam in water (Figure 4B) at laboratory temperature, and hand pollinated with the help of a paintbrush $24 \mathrm{~h}$ after emasculation. Pollen was obtained from flowers at the same balloon stage by removing and drying the anthers at laboratory temperature during $24 \mathrm{~h}$. Pollen grains were sieved by using a fine mesh $(0.26 \mathrm{~mm})$ and then used immediately or frozen at $-20{ }^{\circ} \mathrm{C}$ until further use at laboratory temperature [56]. After $72 \mathrm{~h}$, when the pollen tubes had enough time to reach the ovary [57], pistils were fixed in ethanol $(95 \%) /$ acetic acid $(3: 1, v / v)$ during $24 \mathrm{~h}$, and conserved at $4{ }^{\circ} \mathrm{C}$ in $75 \%$ ethanol [57]. Pollen viability was also evaluated after each pollination. Pollen was scattered on a solidified pollen germination medium [58] and observed under the microscope $24 \mathrm{~h}$ after pollen germination. Pollen grains were considered to be viable when the length of the growing pollen tube was higher than the pollen grain diameter.
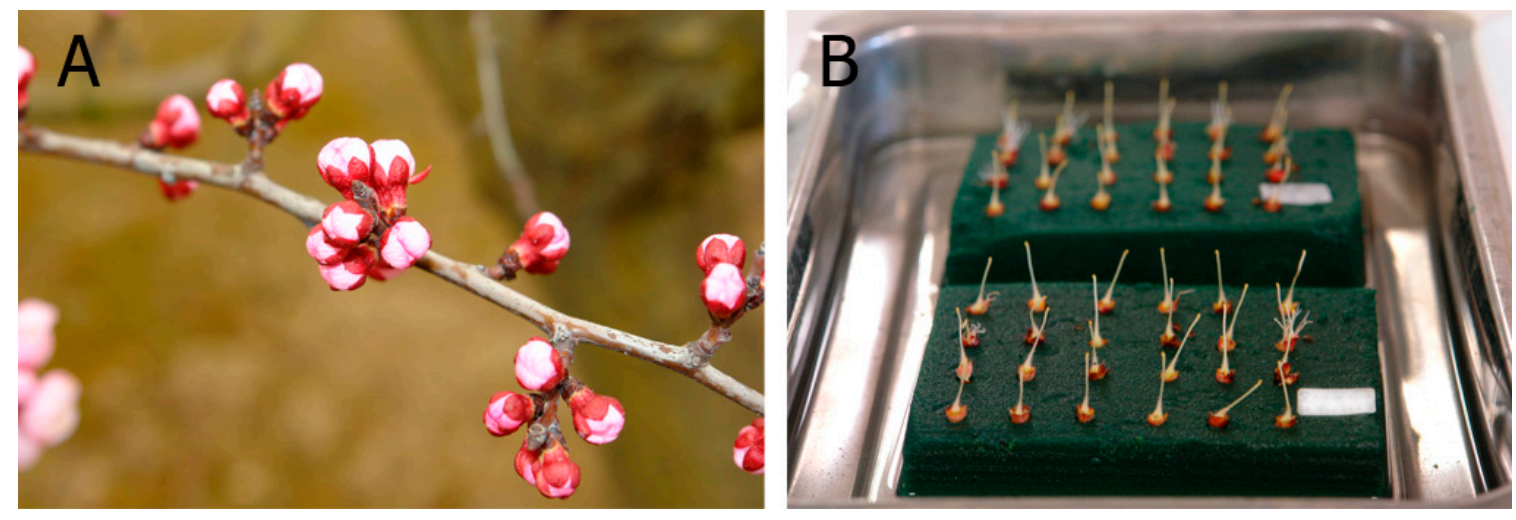

Figure 4. Apricot flowers at balloon stage in the field (A) and pistils on florist foam in water in the laboratory (B).

For histochemical preparations, the pistils were washed three times for $1 \mathrm{~h}$ with distilled water and left in $5 \%$ sodium sulphite at $4{ }^{\circ} \mathrm{C}$. After $24 \mathrm{~h}$, they were autoclaved at $1 \mathrm{~kg} / \mathrm{cm}^{2}$ during $10 \mathrm{~min}$ in sodium sulphite [59] to soften the tissues, squashed, and stained with $0.1 \%(v / v)$ aniline blue in $0.1 \mathrm{~N}$ $\mathrm{K}_{3} \mathrm{PO}_{4}[60]$ to stain callose deposition during pollen tube growth under the microscope $[21,22,24,56,61]$. Pollen tube growth along the style was observed by a Leica DM2500 microscope (Cambridge, UK) with UV epifluorescence using 340-380 bandpass and 425 longpass filters. 
Pollen tube growth was recorded on 8-18 pistils in each self-pollination and at least 4-18 pistils in control crosses. Cultivars were considered as self-compatible when most of the pistils displayed at least one pollen tube reaching the base of the style. Self-incompatibility was considered in self-pollinated flowers when pollen tube growth was arrested along the style in all pistils.

Supplementary Materials: Supplementary materials can be found at http://www.mdpi.com/1422-0067/19/11/ 3612/s1.

Author Contributions: S.H., J.I.H., J.L. and J.R. conceived the study. S.H., J.L., J.R. and J.I.H. designed the experiments and wrote the paper. J.L. performed the sequencing of genomic PCR products. S.H. performed most of the experiments and prepared the final data and figures.

Funding: This research was funded by Ministerio de Ciencia, Innovación y Universidades_European Regional Development Fund, European Union (AGL2016-77267-R, and AGL2015-74071-JIN); Instituto Nacional de Investigación y Tecnología Agraria y Alimentaria (RFP2015-00015-00, RTA2014-00085-00, RTA2017-00003-00); Gobierno de Aragón-European Social Fund, European Union (Grupo Consolidado A12_17R), Fundación Biodiversidad, and Agroseguro S.A.

Conflicts of Interest: The authors declare no conflict of interest.

\section{Abbreviations}

GSI Gametophytic Self-Incompatibility System

SSI Self-Incompatibility System

SI Self-Incompatibility

\section{References}

1. Silva, N.F.; Goring, D.R. Mechanisms of self-incompatibility in flowering plants. Cell. Mol. Life Sci. 2007, 58, 1988-2007. [CrossRef] [PubMed]

2. Barrett, S.C.H. Mating strategies in flowering plants: The outcrossing-selfing paradigm and beyond. Philos. Trans. R. Soc. Lond. B. Biol. Sci. 2003, 358, 991-1004. [CrossRef] [PubMed]

3. Pandey, K.K. Evolution of Incompatibility Systems in Plants: Origin of "Independent" and "Complementary" Control of Incompatibility in Angiosperms. New Phytol. 1980, 84, 381-400. [CrossRef]

4. Raduski, A.R.; Haney, E.B.; Igić, B. The expression of self-incompatibility in angiosperms is bimodal. Evolution 2012, 66, 1275-1283. [CrossRef] [PubMed]

5. Bedinger, P.A.; Broz, A.K.; Tovar-Mendez, A.; McClure, B. Pollen-Pistil Interactions and Their Role in Mate Selection. Plant Physiol. 2017, 173, 79-90. [CrossRef] [PubMed]

6. De Nettancourt, D. Incompatibility and Incongruity in Wild and Cultivated Plants; Springer-Verlang: Berlin/Heidelberg, Germany, 2001; ISBN 978-3-642-08457-7.

7. Gibbs, P.E. Late-acting self-incompatibility-The pariah breeding system in flowering plants. New Phytol. 2014, 203, 717-734. [CrossRef] [PubMed]

8. Barrett, S.C.H. The evolution, maintenance, and loss of self-incompatibility systems. In Plant Reproductive Ecology: Patterns and Strategies; Lovett Doust, J., Lovett Doust, L., Eds.; Oxford University Press: New York, NY, USA, 1988; pp. 84-124.

9. Hegedús, A.; Lénárt, J.; Halász, J. Sexual incompatibility in Rosaceae fruit tree species: Molecular interactions and evolutionary dynamics. Biol. Plant. 2012, 56, 201-209. [CrossRef]

10. Kao, T.; Tsukamoto, T. The Molecular and Genetic Bases of S-RNase-Based Self-Incompatibility. Plant Cell 2004, 16, 72-83. [CrossRef] [PubMed]

11. Brugière, N.; Rothstein, S.J.; Cui, Y. Molecular mechanisms of self-recognition in Brassica self-incompatibility. Trends Plant Sci. 2000, 5, 432-438. [CrossRef]

12. Charlesworth, D.; Vekemans, X.; Castric, V.; Glémin, S. Plant self-incompatibility systems: A molecular evolutionary perspective. New Phytol. 2005, 168, 61-69. [CrossRef] [PubMed]

13. Tao, R.; Yamane, H.; Sassa, H.; Mori, H.; Gradziel, T.M.; Dandekar, A.M.; Sugiura, A. Identification of Stylar RNases Associated with Gametophytic Self-Incompatibility in Almond (Prunus dulcis). Plant Cell Physiol. 1997, 38, 304-311. [CrossRef] [PubMed]

14. Tao, R.; Iezzoni, A.F. The S-RNase-based gametophytic self-incompatibility system in Prunus exhibits distinct genetic and molecular features. Sci. Hortic. 2010, 124, 423-433. [CrossRef] 
15. Ushijima, K.; Sassa, H.; Dandekar, A.M.; Gradziel, T.M.; Tao, R.; Hirano, H. Structural and Transcriptional Analysis of the Self-Incompatibility Locus of Almond: Identification of a Pollen-Expressed F-Box Gene with Haplotype-Specific Polymorphism. Plant Cell 2003, 15, 771-781. [CrossRef] [PubMed]

16. Dirlewanger, E.; Graziano, E.; Joobeur, T.; Garriga-Caldere, F.; Cosson, P.; Howad, W.; Arus, P. Comparative mapping and marker-assisted selection in Rosaceae fruit crops. Proc. Natl. Acad. Sci. USA 2004, 101, 9891-9896. [CrossRef] [PubMed]

17. Burgos, L.; Egea, J.; Guerriero, R.; Viti, R.; Monteleone, P.; Audergon, J.M. The self-compatibility trait of the main apricot cultivars and new selections from breeding programmes. J. Hortic. Sci. 1997, 72, 147-154. [CrossRef]

18. Hormaza, J.I.; Yamane, H.; Rodrigo, J. Apricot. In Fruits and Nuts: Genome Mapping and Molecular Breeding in Plants, Volume IV; Kole, C., Ed.; Springer-Verlag: Berlin/Heidelberg, Germany; New York, NY, USA, 2007; Volume 4, pp. 171-187.

19. Zhebentyayeva, T.; Ledbetter, C.; Burgos, L.; Llácer, G. Apricot. In Fruit Breeding; Badenes, M.L., Byrne, D., Eds.; Springer-Verlang: New York, NY, USA, 2012; ISBN 978-1-4419-0762-2.

20. Rodrigo, J.; Herrero, M.; Hormaza, J.I. Pistil traits and flower fate in apricot (Prunus armeniaca). Ann. Appl. Biol. 2009, 154, 365-375. [CrossRef]

21. Julian, C.; Herrero, M.; Rodrigo, J. Flower bud differentiation and development in fruiting and non-fruiting shoots in relation to fruit set in apricot (Prunus armeniaca L.). Trees 2010, 24, 833-841. [CrossRef]

22. Rodrigo, J.; Herrero, M. Effects of pre-blossom temperatures on flower development and fruit set in apricot. Sci. Hortic. 2002, 92, 125-135. [CrossRef]

23. Hedhly, A.; Hormaza, J.I.; Herrero, M. Effect of temperature on pollen tube kinetics and dynamics in sweet cherry, Prunus avium (Rosaceae). Am. J. Bot. 2004, 91, 558-564. [CrossRef] [PubMed]

24. Herrera, S.; Lora, J.; Hormaza, J.I.; Herrero, M.; Rodrigo, J. Optimizing Production in the New Generation of Apricot Cultivars: Self-incompatibility, S-RNase Allele Identification, and Incompatibility Group Assignment. Front. Plant Sci. 2018, 9, 527. [CrossRef] [PubMed]

25. Guerra, M.E.; Rodrigo, J. Japanese plum pollination: A review. Sci. Hortic. 2015, 197, 674-686. [CrossRef]

26. Nasrallah, J.B.; Kao, T.-H.; Goldberg, M.L.; Nasrallah, M.E. A cDNA clone encoding an S-locus-specific glycoprotein from Brassica oleracea. Nature 1985, 318, 263-267. [CrossRef]

27. Tao, R.; Yamane, H.; Sugiura, A.; Murayama, H.; Sassa, H.; Mori, H. Molecular Typing of S-alleles through Identification, Characterization and cDNA Cloning for S-RNases in Sweet Cherry. J. Am. Soc. Hortic. Sci. 1999, 124, 224-233.

28. Tamura, M.; Ushijima, K.; Sassa, H.; Hirano, H.; Tao, R.; Gradziel, T.M.; Dandekar, A.M. Identification of self-incompatibility genotypes of almond by allele-specific PCR analysis. TAG Theor. Appl. Genet. 2000, 101, 344-349. [CrossRef]

29. Beppu, K.; Yamane, H.; Yaegaki, H.; Yamaguchi, M.; Kataoka, I.; Tao, R. Diversity of $S$-RNase genes and $S$ -haplotypes in Japanese plum (Prunus salicina Lindl.). J. Hortic. Sci. Biotechnol. 2002, 77, 658-664. [CrossRef]

30. Beppu, K.; Takemoto, Y.; Yamane, H.; Yaegaki, H.; Yamaguchi, M.; Kataoka, I.; Tao, R. Determination of S-haplotypes of Japanese plum (Prunus salicina Lindl.) cultivars by PCR and cross-pollination tests. J. Hortic. Sci. Biotechnol. 2003, 78, 315-318. [CrossRef]

31. Sutherland, B.G.; Robbins, T.P.; Tobutt, K.R. Primers amplifying a range of Prunus S-alleles. Plant Breed. 2004, 123, 582-584. [CrossRef]

32. Halász, J.; Hegedus, A.; Hermán, R.; Stefanovits-Bányai, É.; Pedryc, A. New self-incompatibility alleles in apricot (Prunus armeniaca L.) revealed by stylar ribonuclease assay and S-PCR analysis. Euphytica 2005, 145, 57-66. [CrossRef]

33. Vilanova, S.; Romero, C.; Llácer, G.; Badenes, M.L. Identification of Self-(in)compatibility Alleles in Apricot by PCR and Sequence Analysis. J. Am. Soc. Hortic. Sci. 2005, 130, 893-898.

34. Zhang, L.; Chen, X.; Chen, X.; Zhang, C.; Liu, X.; Ci, Z.; Zhang, H.; Wu, C.; Liu, C. Identification of self-incompatibility ( $S-)$ genotypes of Chinese apricot cultivars. Euphytica 2008, 160, 241-248. [CrossRef]

35. Muñoz-Sanz, J.V.; Zuriaga, E.; López, I.; Badenes, M.L.; Romero, C. Self-(in)compatibility in apricot germplasm is controlled by two major loci, $S$ and M. BMC Plant Biol. 2017, 17, 82. [CrossRef] [PubMed]

36. Murathan, Z.T.; Kafkas, S.; Asma, B.M.; Topçu, H. S_allele identification and genetic diversity analysis of apricot cultivars. J. Hortic. Sci. Biotechnol. 2017, 92, 251-260. [CrossRef] 
37. Szabó, Z.; Nyéki, J. Blossoming, fructification and combination of apricot varieties. Acta Hortic. 1991, 293, 295-302. [CrossRef]

38. Egea, J.; Burgos, L. Detecting Cross-incompatibility of Three North American Apricot Cultivars and Establishing the First Incompatibility Group in Apricot. J. Am. Soc. Hortic. Sci. 1996, 121, 1002-1005.

39. Halász, J.; Pedryc, A.; Ercisli, S.; Yilmaz, K.U.; Hegedûs, A. S-genotyping supports the genetic relationships between Turkish and Hungarian apricot germplasm. J. Am. Soc. Hortic. Sci. 2010, 135, 410-417.

40. Lachkar, A.; Fattouch, S.; Ghazouani, T.; Halasz, J.; Pedryc, A.; Hegedüs, A.; Mars, M. Identification of self-(in)compatibility $S$ - alleles and new cross-incompatibility groups in Tunisian apricot (Prunus armeniaca L.) cultivars. J. Hortic. Sci. Biotechnol. 2013, 88, 497-501. [CrossRef]

41. Romero, C.; Vilanova, S.; Burgos, L.; Martínez-Calvo, J.; Vicente, M.; Llácer, G.; Badenes, M.L. Analysis of the S-locus structure in Prunus armeniaca L. Identification of S-haplotype specific S-RNase and F-box genes. Plant Mol. Biol. 2004, 56, 145-157. [CrossRef] [PubMed]

42. Feng, J.; Chen, X.; Wu, Y.; Liu, W.; Liang, Q.; Zhang, L. Detection and transcript expression of S-RNase gene associated with self-incompatibility in apricot (Prunus armeniaca L.). Mol. Biol. Rep. 2006, 33, $215-221$. [CrossRef] [PubMed]

43. Halász, J.; Pedryc, A.; Hegedus, A. Origin and dissemination of the pollen-part mutated $S_{c}$ haplotype which confers self-compatibility in apricot (Prunus armeniaca). New Phytol. 2007, 176, 792-803. [CrossRef] [PubMed]

44. Wu, J.; Gu, C.; Zhang, S.L.; Zhang, S.J.; Wu, H.Q.; Heng, W. Identification of s-haplotype-specific S-RNase and SFB alleles in native Chinese apricot (Prunus armeniaca L.). J. Hortic. Sci. Biotechnol. 2009, 84, 645-652. [CrossRef]

45. Egea, J.; Ruiz, D.; Burgos, L. “ Dorada” Apricot. HortScience 2005, 40, 1919-1920.

46. Egea, J.; Ruiz, D.; Dicenta, F.; Burgos, L. “ Murciana ” Apricot. HortScience 2005, 40, 254-255.

47. Mehlenbacher, S.A.; Cociu, V.; Hough, F.L. Apricots (Prunus). Acta Hortic. 1991, 290, 65-110. [CrossRef]

48. Alburquerque, N.; Egea, J.; Pérez-Tornero, O.; Burgos, L. Genotyping apricot cultivars for self-(in)compatibility by means of RNases associated with S-alleles. Plant Breed. 2002, 121, 343-347. [CrossRef]

49. i Company, R.S.; Kodad, O.; i Martí, A.F.; Alonso, J.M. Mutations conferring self-compatibility in Prunus species: From deletions and insertions to epigenetic alterations. Sci. Hortic. 2015, 192, 125-131. [CrossRef]

50. Vilanova, S.; Badenes, M.L.; Burgos, L.; Martínez-Calvo, J.; Llácer, G.; Romero, C. Self-Compatibility of Two Apricot Selections Is Associated with Two Pollen-Part Mutations of Different Nature. Plant Physiol. 2006, 142, 629-641. [CrossRef] [PubMed]

51. Kodad, O.; Hegedûs, A.; Halász, J. Self-(in)compatibility genotypes of Moroccan apricots indicate differences and similarities in the crop history of European and North African apricot germplasm. BMC Plant Biol. 2013, 13, 196. [CrossRef] [PubMed]

52. Hormaza, J.I. Molecular characterization and similarity relationships among apricot (Prunus armeniaca L.) genotypes using simple sequence repeats. Theor. Appl. Genet. 2002, 104, 321-328. [CrossRef] [PubMed]

53. Sonneveld, T.; Tobutt, K.R.; Robbins, T.P. Allele-specific PCR detection of sweet cherry self-incompatibility (S) alleles $S_{1}$ to $S_{16}$ using consensus and allele-specific primers. Theor. Appl. Genet. 2003, 107, 1059-1070. [CrossRef] [PubMed]

54. Zuriaga, E.; Muñoz-Sanz, J.V.; Molina, L.; Gisbert, A.D.; Badenes, M.L.; Romero, C. An S-Locus Independent Pollen Factor Confers Self-Compatibility in "Katy" Apricot. PLoS ONE 2013, 8, e53947. [CrossRef] [PubMed]

55. Pérez-Pastor, A.; Ruiz-Sánchez, M.C.; Domingo, R.; Torrecillas, A. Growth and phenological stages of Búlida apricot trees in south-east Spain. Agronomie 2004, 24, 93-100. [CrossRef]

56. Rodrigo, J.; Herrero, M. Evaluation of pollination as the cause of erratic fruit set in apricot "Moniqui". J. Hortic. Sci. 1996, 71, 801-805. [CrossRef]

57. Williams, J.H.; Friedman, W.E.; Arnold, M.L. Developmental selection within the angiosperm style: Using gamete DNA to visualize interspecific pollen competition. Proc. Natl. Acad. Sci. USA 1999, 96, 9201-9206. [CrossRef] [PubMed]

58. Hormaza, J.I.; Pinney, K.; Polito, V.S. Correlation in the tolerance to ozone between sporophytes and male gametophytes of several fruit and nut tree species (Rosaceae). Sex. Plant Reprod. 1996, 9, 44-48. [CrossRef]

59. Jefferies, C.J.; Belcher, A.R. A Fluorescent Brightener used for Pollen Tube Identification In Vivo. Stain Technol. 1974, 49, 199-202. [CrossRef] [PubMed] 
60. Linskens, H.F.; Esser, K. Über eine spezifische Anfärbung der Pollenschläuche im Griffel und die Zahl der Kallosepfropfen nach Selbstung und Fremdung. Naturwissenschaften 1957, 44, 16. [CrossRef]

61. Burgos, L.; Berenguer, T.; Egea, J. Self- and Cross-compatibility among Apricot Cultivars. HortScience 1993, $28,148-150$. 